\title{
The Impact of the Entrepreneur and Firm Related Factors on Small and Medium Enterprise Sales Growth
}

\author{
Ajtene Avdullahi ${ }^{1}$, Vjosa Fejza Ademi2* \\ ${ }^{1}$ Doctor of Entrepreneurship and SMEs Management, University of Mitrovica "Isa Boletini” Kosovo \\ 2* Doctor of Marketing Sciences - University of Prishtina "Hasan Prishtina” Kosovo
}

\begin{tabular}{ll}
\hline ARTICLE INFO & A \\
\hline Article History & I \\
& in \\
Received 20 April 2020 & Accepted 28 May 2020 \\
\hline JEL Classifications & m
\end{tabular}

L25, L26

ABSTRACT
Purpose:

In nowadays economy, the role of Small and Medium Enterprises (SMEs) is continually increasing as they represent the primary source of employment, economic development, poverty alleviation, new product development, and innovations. The SMEs' growth depends mostly upon its internal factors like the entrepreneur related factors and firm related factors. The main objective of this research is to explore how these internal factors influence SMEs' sales growth.

Design/methodology/approach:

For our research purpose, we have used a sample of 600 business owners of SMEs across Kosovo, and the multivariate regression analysis is developed to test the four hypotheses that we have set.

\section{Findings:}

In our research, we did not find any significant statistical relation for the positive effect of the entrepreneur's education on SMEs' sales growth. We found negative support to our hypothesis: Female Entrepreneurs will be positively related to SMEs' sales growth. Our research results indicate that variable Business age have an impact on the firm's sales, whereas, regarding the firm size, our results indicate that the bigger is the number of employees within a firm, the firm will experience the higher sales growth.

Research implications:

Based on our research results, we suggest that entrepreneurs should attend long-term and high quality training considering their positive effects on the firms' growth, whereas female entrepreneurs and managers should improve their management and business skills, cash flow and, technical skills and create sustainable networks.

Keywords:

Entrepreneur's education, entrepreneurs' gender, firms' age, firms' size, SMEs' sales growth.

Originality/value:

This paper will contribute to existing theory by filling the gap in the literature on the impact of the entrepreneur and firm related factors on small and medium enterprise growth with empirical evidence from a unique transitional country.

\section{Introduction}

SMEs are considered as a significant factor for economic growth in any economy. Their importance is well known worldwide as the generator of employment and innovations. In Kosovo the unemployment rate is the highest when compared to the other countries of the region. For the period from 2001 until 2019, the average unemployment rate in Kosovo was 34.69 percent, in the fourth quarter of 2001 reached an all-time high of 57 percent and in the third quarter of 2019, a record low of 24.50 percent was recorded (Trading Economics, 2020).

The unfavorable economic conditions in Kosovo disables the government to generate new working places and decrease unemployment. Therefore, the development of entrepreneurship and SMEs remains as the main provisions for economic growth, employment, and social welfare in Kosovo. The main purpose of this research is to identify how internal factors such as the entrepreneur related factors and firm related factors have an impact on SMEs' growth. This paper intends to identify which is the contribution of the entrepreneur's age and gender to SMEs growth and to explore the impact that the firm's age and size have on the SMEs' growth. Given the gap in the literature on the impact of the entrepreneur and firm related factors on small and medium enterprise growth from transition

* Corresponding Author: Vjosa Fejza Ademi

Email: vjosa.fejza@uni-pr.edu 
developing countries, the overall purpose of this research is to contribute to existing theory with empirical evidence from a unique transitional country - Kosovo.

\section{Theoretical background}

Firm's growth presents one of the main concerns of entrepreneurs and researchers for many decades: since it has been discussed and measured in many different ways (Davidsson and Wiklund, 2000). According to Penrose (1959), the term "growth" sometimes presents only an increase in an amount, e.g., growth in profit, sales, production, export, whereas sometimes, it is used indicating an enhancement in quality after a process improvement. Whetten (1987) has operationalized the distinction between growth and size, who indicated that size, is an absolute measure, while growth is a relative measure of size throughout time. Based on numerous theories, growth appear in many different forms of a company's operations, such as sales, market share, clientele, employment, and cash flow (Murphy et al., 1996).

After reviewing the literature from 48 empirical studies Gilbert et al., (2006) concluded that there is no single overriding measure of new firm growth, and the most important measures are in terms of employment, sales, and its share of the market. According to Robinson (1999) sales growth provides information about revenue trends throughout time and presents information on the acceptance level of the firm's products or services. Thus, sales present the most frequently used indicator of new firm growth (Murphy et al., 1996). When firms experience sales growth, it is supplied with revenues that can be directed towards increasing the resources or developing capabilities (Gilbert et al., 2006). However, we are interested in exploring the factors that influence the performance of firms. Based on the literature review, the main determinants of small business performance are the entrepreneur demographics and firm characteristics factors (Cragg and King, 1993). Whereas, the demographic characteristics of an entrepreneur such as age, gender, education, and previous experience in the industry, are essentials for business success (Khan et al., 2011). Entrepreneurship is traditionally associated with masculine traits and image (Gupta et al., 2009). Particularly, the dominance of a masculine stereotype associated with entrepreneurship may lead women to evaluate business opportunities less favourably (Gupta et al., 2009), as compared to men. According to Dimitriadis et al. (2018), studies conducted in the majority of Western countries identify three main barrier-types to female entrepreneurship, which are related to the socio-cultural status of women (which identifies the primary role of women with family and domestic responsibilities and reduces the credibility of women intent on setting up businesses in a variety of ways), the access to networks of information and assistance, and finally, access to capital. Also, based on research conducted in Montenegro, The male-self-employed population is $21.3 \%$ almost double of the female population at $8.9 \%$, which is indicative of much less opportunity for the female entrepreneurs (Karadzic, Drobnjak, \& Reyhani, 2015). Whereas in Kosovo's economy only 10\% of the total businesses in Kosovo are owned by female entrepreneurs, and the majority of these enterprises are the micro and small business (Mehmeti, Dobranja, Hashani, \& Beqiri, 2017).

As stated by Bartlett and Bukvic (2001), large firms were typically expected to have advantages over small firms and grow more rapidly due to economies of scale and scope. However, the numerous literature on research studies coming from different countries proves the opposite of these expectations. Hart (2000), has reviewed empirical research on the growth of U.K. and U.S.A companies. He pointed out that "most studies relating to periods since 1885 shows that small firms grow more quickly than larger firms".

In Germany, Alnus and Nerlinger, (2000), revealed a negative relationship between growth and firm size. Scholars have widely accepted the relationship between entrepreneurial orientation and firm performance. Anderson and Eshima (2013) investigated in Japan the influence of firm age and intangible resources to its respective rivals on the entrepreneurial orientation firm growth relationship among SMEs. They pointed out that the firms' age and its intangible resource would represent theoretically meaningful limited provisions on the entrepreneurial orientation firm growth relationship among SMEs.

By bringing the research from Kosovo, this study provides a contextualized view of the impact of the entrepreneur's gender and education as well as the firm's age and size on SMEs' growth in terms of firm's sales.

\section{Research objective, methodology and data}

The main research questions of this research paper are:

- What is the contribution of the entrepreneurs' age and gender to SMEs' sales growth?

- $\quad$ Does the firms' age and size have an impact on SMEs' sales growth?

Therefore, the following four hypotheses are set and ranked into two main groups. It is hypothesized that entrepreneurs' attributes, e.g., education and gender, will be positively related to SMEs' sales growth; thus, the following hypotheses were set.

Hypothesis 1: Entrepreneurs' education is positively related to SMEs' sales growth.

According to Bardasi et al., (2011), the relationship between entrepreneurial performance and gender is intriguing. Substantial gender-specific constrained obstacles hinder the performance of female entrepreneurs. Therefore, aiming to test whether this statement stands in our research, we hypothesized the following:

Hypothesis 2: Female Entrepreneurs are positively related to SMEs' sales growth.

Regarding the firm-related characteristics, e.g., Firms age and size we hypothesized the following

Hypothesis 3: The firms' age does not have any impact on the SMEs' sales growth.

Hypothesis 4: The firms' size is positively related to SMEs' sales growth.

DOI: $10.25103 /$ ijbesar.131.06 
The methodological position of the research in this paper rests on the use of the quantitative methodology. Creswell (1994) stated that a quantitative study is explained as an inquiry into social or human problems based on testing a theory consist of variables, measured with numbers and, analyzed with statistical procedures in order to determine whether the anticipated conclusions of the theory hold. Quantitative research experts accurately emphasize measurement variables and test hypotheses, which relate to general causal explanations (Newman, 2006). In this research study the cross-sectional research design is adopted, by using quantitative data at one point in time.

For our research purpose, we will use secondary data gathered from Riinvest (a non-profit research institute of Kosovo), who developed a survey that was conducted with a representative sample of 600 business owners of SMEs across Kosovo in 2011. The sample is drawn using a random selection from the business register that was kept at the Tax Administration of Kosovo. The procedure for selecting the sample size and companies to be interviewed was performed by the Riinvest team in Excel using the random command. The sample was stratified by the size of the company's category.

For the research purpose, we will use a survey that was prepared and conducted by Riinvest. The data obtained from the questionnaire were analyzed using the designed linear regression econometric model for investigating the firms' sales influencing factors.

\subsection{Measurement of Study Variables}

\subsubsection{Dependent Variable}

According to the Law of Proportionate Effect or the Gibrat's rule of proportionate growth, the growth of a firm does not depend on the size of the firm (Rosli and Sidek, 2013). The law of Gibrat anticipates the firms' growth as a random effect that is independent of firms' size (Gibrat, 1931). According to the reviewed literature, employment and sales are, the most widely used indicators for a firms' growth (Davidsson, 1991; Delmar, 1997; Ardishvili et al., 1998; Weinzimmer et al., 1998; Wiklund 1998). According to Zhou and De Wit (2009), the most commonly used indicators are employment and growth in sales, mainly as they immediate changes in a firm in both: short-term and long-term, and as they are easy to obtain. Employment and sales are more objective measures compared to other indicators, such as market shares (Delmar, 1997). Thus, for research purposes in this chapter, we will measure the firms' growth in terms of SME sales.

\subsubsection{Independent Variables}

An independent variable is that variable that is changed and whose effects are measurable and compared. As seen in table 1 in this research, independent variables are grouped into two categories: human capital related variables and firm related variables.

\section{Human Capital related variables}

For our research purpose, we have chosen some of the characteristics of human capital as the first group of variables. Similar to some previous authors we argue that generic human capital applies to the knowledge that the entrepreneurs or employees obtain in regular education, whereas specific human capital applies to tacit knowledge and skills and that are less transferable (Gimeno et al., 1997; Hoxha 2013). According to Akinboade (2015), the increased level of owner's education is associated with improved turnover growth. We have included variable education as a proxy for general human capital. Entrepreneurs specified their educational level, we have measured their education on a three-point scale (ranging from 1=Elementary School, 2=Secondary School, and 3=University Degree, Master's, and Doctoral Degree). Moreover, we control for the gender of the entrepreneur (1=Male, $2=$ Female).

\section{Firm related variables}

Regarding the firm related variables, as Kimberley (1976) stated, the most widely used measure of size is the number of employees. Thus, we included the variable business size that presents the firm's number of employees. Variable business age (with this variable, we have measured the number of years since the firm has been founded) is also included.

Table 1. List of explanatory (independent) variables

\begin{tabular}{|c|c|c|}
\hline Category & Variables & Definition \\
\hline \multirow[b]{2}{*}{$\begin{array}{l}\text { Human } \\
\text { Capital }\end{array}$} & Gender & $1=$ Male, $2=$ Female \\
\hline & Education & $\begin{array}{l}1=\text { Elementary School, } 2=\text { Secondary School } \\
\text { and } 3=\text { University Degree, Master's and } \\
\text { Doctoral Degree }\end{array}$ \\
\hline \multirow[b]{2}{*}{ Firm } & Firms Age & Number of years the firm has been founded \\
\hline & Firms Size & $\begin{array}{l}\text { The number of employees in the firm in } \\
2011 \text { (indicate number) }\end{array}$ \\
\hline
\end{tabular}




\section{Results and discussion}

In this chapter, the obtained results of this research are presented. Initially, in the regression analysis are introduced the correlations of the variables. Afterward, the research model about SMEs' growth in terms of sales is discussed.

The multivariate regression analysis was used to analyze the effect of independent variables on the dependent variable. The independent variables of this research paper are marked with X, namely X1 - Entrepreneurs education, $\mathrm{X}_{2}$ - Gender of Entrepreneur, X3 - Business age, X4-Business size. Whereas, the dependent variable is marked with Y, which in our case, presents - Firm's sales. The dependent variable is metric, where this fact has prompted us to apply in our paper this econometric model presented below.

Below is presented the formula for calculation of the multivariable regression analysis (Trek, 2017):

$$
Y=\beta o+\beta 1 X 1+\beta 2 X 2+\beta n X n
$$

In table 2 are presented the multivariate regression analysis.

Table 2. Multivariate regression analysis

\begin{tabular}{|l|r|r|r|r|}
\hline & $\mathrm{R}$ & R Square & Adjusted R Square & $\begin{array}{c}\text { Std. Error of the } \\
\text { Estimate }\end{array}$ \\
\hline 1 & $.342^{\mathrm{a}}$ & .117 & .111 & .391 \\
\hline
\end{tabular}

a. Predictors: (Constant), Entrepreneurs Education, Number of Employees, Gender of Entrepreneur, Business Age

As shown in Table 2, based on the data, the $\mathrm{R}$-value (multivariate correlation coefficient) is $\mathrm{R}=0.342$; thus, we can conclude that it represents a relative satisfaction prediction level for dependent variable Y (firm's sales). The value of $\mathrm{R}$ squared (determination coefficient) is $\mathrm{R} 2=0.117$, and the calculated standard deviation is 0.391 . The result of $\mathrm{R} 2=$ 0.117 , shows that the independent variables $(\mathrm{X})$ included in this model can interpret $11.7 \%$ of the variability of dependent variable Y, the firms' sales. Table 3 depicts the variance analysis statistical test - ANOVA.

Table 3. Results of the variance analysis statistical test ANOVA ${ }^{\mathrm{a}}$

\begin{tabular}{|cl|c|c|c|c|c|}
\hline & & & & Mean & & \\
Model & Sum of Squares & df & Square & F & Sig. \\
\hline \multirow{2}{*}{1} & Regression & 11.102 & 4 & 2.775 & 18.144 & $.000^{\mathrm{b}}$ \\
& Residual & 83.674 & 547 & .153 & & \\
& Total & 94.775 & 551 & & & \\
\hline
\end{tabular}

a. Dependent Variable: Firm Sales

b. Predictors: (Constant), Entrepreneurs Education, Number of Employees, Gender of Entrepreneur, Business Age

According to the data presented above in Table 3, we can conclude that the dependent variable Y (firm's sales) has significant relations with all independent variables $\mathrm{X}$, with the value reaching $\mathrm{F}(4,547)=18.144$, and significance value $p=0.000$ (that presents significant value, considering that the p resulted in being under the value of 0.05 ).

In table 4 are shown the test results of the independent variable in order to be discovered if there is any statistical significance between them. Aiming to reach our objective to investigate the influencing factors of the growth of SMEs in terms of SMEs sales in Kosovo, the large dataset based on the Riinvest SMEs Survey was employed to estimate the influence of a variety of factors affecting SMEs growth and performance, e.g., entrepreneurs attributes (gender and education) will be positively related to SMEs growth.

In table 4 are presented the results of linear regression model estimating factors influencing the firms' sales. The t-test is implemented in table 4 , in order to support or reject hypotheses from $\mathrm{H}_{1}$ to $\mathrm{H} 4$. Based on our results on the level of significance, it detects two from four independent variables are statistically significant with the significance levels under $p<0.05$. The variables Number of Employees $(p=0.000)$ and Gender of Entrepreneur $(p=0.031)$ are statistically significant, while the $\mathrm{p}$ values were under the significance level required $\mathrm{p}<0.05$. 
Table 4: Results from the linear regression model Variables in the equation

Coefficients ${ }^{\mathrm{a}}$

\begin{tabular}{|c|c|c|c|c|c|c|}
\hline & \multirow{2}{*}{ Model } & \multicolumn{2}{|c|}{ Unstandardized Coefficients } & \multirow{2}{*}{$\frac{\text { Standardized Coefficients }}{\text { Beta }}$} & \multirow[b]{2}{*}{$\mathrm{t}$} & \multirow[b]{2}{*}{ Sig. } \\
\hline & & $\mathrm{B}$ & Std. Error & & & \\
\hline \multirow[t]{5}{*}{1} & (Constant) & 1.199 & .090 & & 13.266 & .000 \\
\hline & Business Age & .002 & .002 & .047 & 1.170 & .242 \\
\hline & $\begin{array}{l}\text { Number of } \\
\text { Employees }\end{array}$ & .009 & .001 & .311 & 7.702 & .000 \\
\hline & $\begin{array}{l}\text { Gender of } \\
\text { Entrepreneur }\end{array}$ & -.116 & .054 & -.087 & -2.164 & .031 \\
\hline & $\begin{array}{l}\text { Entrepreneurs } \\
\text { Education }\end{array}$ & .036 & .028 & .051 & 1.269 & .205 \\
\hline
\end{tabular}

a. Dependent Variable: Firms' Sales

(Dependent variable is categorical $1=$ firm's sales $<50.000$; 2=firm's sales $\leq 2.000 .000$; $3=$ firm's sales $\leq 10.000 .000$ and $4=$ firm's sales $>10.000 .000)$

\subsection{Entrepreneur related factors (gender and education)}

The hypothesis H1: "Entrepreneur's Education will be positively related to SMEs' sales growth" is rejected, considering that the significance value result for the "entrepreneur's education" (independent variable), exceeds 0.05 as $\mathrm{p}=0.205$. Many authors elaborated on the impact that the entrepreneur's education has on SMEs' performance and growth. Akinboade (2015) indicates that the owners' level of education affects SMEs' efficiency. Besides, Bhutta et al., (2008) found a positive impact that education has on the firm's performance. Our results weakly support previous findings in developed countries (Storey, 1994; Greve and Salaff, 2003; Sapienza and Grimm, 1997; Akinboade 2015; Bhutta et al., 2008) and differ to some extent from previous findings in Kosovo concerning the negative impact of formal education of entrepreneurs on start-up growth and size (Hoxha, 2013). Most of the young entrepreneurs were educated during the war and pre-war period, whereas it was the decade of enforced measures and later armed conflict that caused the human damage that affected mainly the younger generation since they did not have proper access to primary, secondary and higher education.

Regarding our hypothesis on the positive impact of female entrepreneurs on SMEs sales, we found a negative impact of female entrepreneurs on SMEs' sales growth.

Besides, hypothesis H2: "Female Entrepreneurs will be positively related to SMEs' sales growth" is supported, being that its significance value of $p=0.031$ is lower than the standard required for this value $(p<0.05)$. Further, the Beta $\mathrm{B}$ value $=-.087$ is a negative value, which shows the indirect relationship between these two variables.

According to Akinboade (2015), there is no relationship between gender and firm growth in terms of sales. Furthermore, some research papers suggest a positive association between firm growth and gender (Farrell and Hersch 2005). Hassan et al., (2016), attempting to examine the gender diversity effect among corporate boards on the market value, found that participation of women does have an association with raising the value of the market. Whereas, an earlier study found a negative relationship between firm growth and female on board (Shrader et al., 1997).

\subsection{Firm related-factors (SMEs size and age)}

According to Expósito and Sanchis Llopis, (2019), characteristics of a firm, such as firm age and size, are not major antecedents of the performance of a business, whereas the firms that seem to enjoy a higher probability of better performance in operational measures are only those of medium-sized ones. In our research, Hypothesis H3: "Bussines age does not have any impact on the firm's sales" is rejected, being that its significance value of $p=0.242$ exceeds the standard $\mathrm{p}<0.05$, proving that these two variables do not have a significant statistical relation.

Hypothesis H4: "Firms size will be positively related to SMEs sales growth," is highly supported, considering that the significance value of $\mathrm{p}=0.000$ in under the standard required value of $\mathrm{p}<0.05$, which means that there are significant relations between these two variables indicating that which means the more employees the firm has will experience higher sales growth

\section{Conclusion and Recommendations}

In this research, our primary purpose was to identify how the entrepreneur related factors and firm related factors as internal factors have an impact on SMEs' growth. For our research purpose, the Riinvest data are used with a sample of 600 business owners of SMEs across Kosovo. In general, the research questions were set to investigate the contribution of the entrepreneurs' and firm related factors to SMEs' sales growth. Based on our curiosity and research interest, we have set four hypotheses to be tested. Concerning our first research question: "What is the contribution of the entrepreneur's education and gender to SMEs sales growth?" based on the research results, is revealed the importance of the entrepreneur's attributes, e.g., education and gender on SMEs sales growth. In our research, it was not identified any significant statistical relation for the positive impact of an entrepreneur's education on SMEs' sales 
growth. Our results are in line with Hoxha (2013) indicating that it is mainly due to the extreme condition of SMEs growth, where education has no significant role in the firm's growth or the quality of entrepreneur's education, probably lack to offer the practical skills that would enhance the entrepreneurs' capacity to manage the firm's growth and performance. In this research is evident the performance gap among male and female entrepreneurs that presents the main starting point to explore and increase the literature on gender gaps and female entrepreneurship. It can be concluded that if inefficiencies exist it means that in certain economies human capital is not being fully utilized and SMEs growth remains an issue with a particular focus for many researchers (Bardasi et al., 2011).

Our research results are in line with numerous previous research findings, whereas we found negative support to our hypothesis, "Female Entrepreneurs will be positively related to SMEs sales growth," which confirms the inverse relationship among these variables. Numerous research papers have elaborated on the obstacles that female entrepreneurs face while launching and managing their businesses. According to the findings from a study that was done by Gobagoba and Littrell, (2003), female entrepreneurs faced a variety of obstacles such as lack of management, business and, financial skills; technical skills; the ability to recruit qualified staff; the limited access to appropriate technology and, have difficulties in sustainable networking. Based on the evidence from the United States, it can be concluded that businesses owned by males are twice as larger than businesses owned by females, in terms of both assets and sales (Coleman 2007).

According to Robb and Wolken (2002), on average, female-owned businesses generate only $78 \%$ of the profits of comparable male-owned businesses. Besides, it is found that women lag behind the man to generate sales turnover, even in the same sector of industry (Loscocco and Robinson 1991; Chaganti and Parasuraman 1996).

However, many researchers found contrasting results, e.g. (Barbadasi et al., 2007) based on the World Bank Enterprise Surveys (2002-2006), found that when measured by total factor productivity and value-added per worker, businesses owned by females are at least as productive as those of male-owned businesses. Our results differ from Kepler and Shane (2007), indicating that there are no significant differences in gender in terms of the performance outcomes of startup entrepreneurs. Numerous literatures indicate that businesses owned by females do not lag in performance when comparing in terms of employment creation (Fischer et al., 1993; Chaganti and Parasuraman 1996) or survival rates in the market (Kalleberg and Kevin 2017; Bruderl and Preisendorfer 1998).

Concerning our second research question: Do the firms' age and size have an impact on the SMEs' sales growth? Our findings show that variable Business age have an impact on the firms' sales. Our research results are in line with Jovanovic's model (Jovanovic 1982) that introduces the growing dependency on age, considering that our findings do suggest that older firms have a higher level of sales growth compare to the younger firms and startups. Our last hypothesis in this research, "Firms size will be positively related to SMEs sales growth," is highly supported, strengthening the argument that our research does not hold the Gibrat Law.

Overall, the obtained results of this research paper have contributed to strengthening the existing theory with new evidence from human capital theory on the SMEs' performance, in a transition country. Based on our results regarding entrepreneurs' attributes, e.g., education on SMEs' sales growth, we did not find any significant statistical relation for the positive impact of an entrepreneur's education on SMEs' sales growth. Thus, we suggest that entrepreneurs and managers must attend long-term and high-quality trainings considering their positive effects on the firms' growth. Based on our results concerning female entrepreneurs and their negative impact on SMEs' sales growth, we suggest that female entrepreneurs and managers should improve their managerial and business skills, cash flow and, technical skills and create sustainable networks. Based on recent literature, the performance of femaleowned businesses is increasing worldwide. Therefore, it is expected that this trend of the positive impact of female entrepreneurs on business performance will be evident very soon in Kosovo as well, given the Kosovo governments' institutional support to female entrepreneurs. The government should invest in developing an online information platform for female entrepreneurs to keep them informed with the sources of support such as financial support, training and, organizing trade fairs in order to promote local products and services of Kosovan female entrepreneurs. From all financial institutions in Kosovo, only three of them offer lending products and packages with preferential terms and conditions to support female entrepreneurs and boost female entrepreneurship (Avdullahi \& Fejza Ademi, 2020). Considering this, we propose to increase the number of loans and credit packages that support women's entrepreneurship.

This research study has an exploratory and interpretive nature on the impact of internal factors on SMEs' sales growth. Although SMEs' growth depends mostly upon its internal factors such as entrepreneur's education and gender as well as SMEs age and size still many other internal and external factors affect the performance and growth of SMEs. The business environment can be supportive in many countries but in transition countries mainly bring barriers to doing business. The informal economy, taxes too high and corruption presents some of the main barriers of SMEs in Kosovo. SMEs sales growth depends also on the strategic decisions on new product development and new marketing practices. Therefore, despite the importance of the results of this paper, the exploration of the impact of some internal factors, without including other internal and external factors, can be considered as a limitation of this paper. This limitation leads to future research that will include both internal and external factors that have an impact on SMEs sales growth and thus have more holistic results. 
Achtenhagen, L., Naldi, L., Melin, L. 2010. 'Business Growth' - Do Practitioners and Scholars Really Talk About the Same Thing? Entrepreneurship Theory and Practice, 34(2). DOI: 10.1111/j.1540-6520.2010.00376.x

Akinboade, O.A. 2015. Determinants of SMEs growth and performance in Cameroon's central and littoral provinces' manufacturing and retail sectors. African Journal of Economic and Management Studies, 6(2), 183-196. DOI:10.1 108/AJEMS-032013-0033

Alnus, M., Nerlinger, E.A. 2000. Testing “Gibrat's Law” for young firms - empirical results for West Germany. Small Business Economics, 15(1), 1-12. DOI:10.1023/A:1026512005921

Anderson, B.S., Eshima, Y. 2013. The influence of firm age and intangible resources on the relationship. Journal of Business Venturing, 28(3), 413-429. DOI:10.1016/j.jbusvent.2011.10.001

Anupindi, R., Chopra, S., Deshmukh, S. D., Van Mieghem, J. A., \& Zemel, E. (2012). Managing Business Process Flows. New Jersey: Pearson

Ardishvili, A., Cardozo, R.N., Harmon, B., Vadakath, S. 1998, May 21-23. Towards a theory of new venture growth. Paper presented at the 1998 Babson Entrepreneurship Research Conference.

Avdullahi, A., \& Fejza Ademi, V. (2020). Lending Conditionsand and Marketing Strategies of Financial Institutions in Kosovo to Support Access to Finance for Women Entrepreneurs. International Journal of Entrepreneurship and Business Development, 3(2), 111-120. doi:https://doi.org/10.29138/ijebd.v3io2.980

Barbadasi, E., Blackden, M., Guzman, J. 2007. Gender, Entrepreneurship and Competitiveness in Africa. World Bank, 69-85.

Bardasi, E., Sabarwal, S., Terrell, K. 2011. How do female entrepreneurs perform? Evidence from three developing regions. Small Business Economics, 37(4), 417-441. DOI:10.1007/s11187-011-9374-Z

Bartlett, W., Bukvic, V. 2001. Barriers to SME growth in Slovenia. MOCT-MOST Economic Policy in Transitional Economics, 11(2), 177-195. DOI:10.1023/A:1012206414785

Bartlett, W., Bukvic, V. 2001. Barriers to SME growth in Slovenia. MOST, 11(1), 77-95.

Becker, J., Kugeler, M., \& Rosemann, M. (2003). Process management (eds.). Berlin: Springer Verlag.

Beck C.H. (n.d.). Table of Contents. Retrieved January 15, 2013, from C.H.Beck: http://www.beckshop.de/fachbuch/inhaltsverzeichnis/9783642151897_TOC_OO1.pdf

Bhutta, K.M., Rana, A.I., \& Usman, A. 2008. Owner characteristics and health of SMEs in Pakistan. Journal of Small Business and Enterprise Development, 15(1), 130-149. DOI:10.1108/14626000810850883

Bosilj, V. V., Hernaus, T., \& Kovačić, A. (2008). Upravljanje poslovnim procesima - organizacijski i informacijski pristup. Zagreb: Školska knjiga.

Bruderl, J., Preisendorfer, P. 1998. Network Support and the Success of Newly Founded Businesses. Small Business Economics, 10(3), 213-225.

Burlton, R. (2001). Business Process Management:Profiting from process. Indianopolis: Sams. Retrieved January 15, 2013, from Process Renewal Group: http://processrenewal.com/files/Overview_Article_about_BPM_.pdf

Byrne, J. A. (1993). The Virtual Corporation. Business Week, 20 December, 98-103.

Chaganti, R., Parasuraman, S. 1996. A study of the impacts of gender on business performance and management pat- terns in small business. Entrepreneurship Theory and Practice, 27(2), 73-75.

Coleman, S. 2007. The Role of Human and Financial Capital in the Profitability and Growth of Women-Owned Small Firms. Journal of Small Business Management, 45(3), 303-319. DOI:10.1111/j.1540-627X.2007.00214.x

Cragg, P.B., King, M. 1989. Organizational Characteristics and Small Firms' Performance Revisited. Entrepreneurship theory and practice, 13(2), 49-64.

Cragg, P., King, M. 1993. Small-firm computing: motivators and inhibitors. MIS Quarterly, 17(1), 47-60. DOI: 10.2307/249509

Creswell, J.W. 1994. Research Design: Qualitative and Quantitative Approaches. Thousand Oaks, CA:.

Davidsson, P. 1991. Continued entrepreneurship: Ability, need, and opportunity as determinants of small firm growth. Journal of Business Venturing, 6(6), 405-429. DOI:10.1016/0883-9026(91)90028-C

Davidsson, P., Wiklund, J. 2000. Conceptual and empirical challenges in the study of firm. In D. Sexton, H. Landström, The Blackwell Handbook of Entrepreneurship (pp. 26-44). Oxford: MA: Blackwell Business Blackwell Publishers Ltd DOI:10.1002/9781405164214

Delmar, F. 1997. Measuring growth: methodological considerations and empirical results ${ }^{e}$, In: Donckels, R., A. Miettinen, (Eds.), pp. 199-2 16,. In R. A. Donckels, Entrepreneurship and SME Research: On its Way to the Next Millennium (pp. 199-216). Aldershot, UK: Ashgate.

Dimitriadis, E., Anastasiades, T., Karagiannidou, D., \& Lagaki, M. (2018). Creativity and Entrepreneurship: The role of Gender and Personality. International Journal of Business and Economic Sciences Applied Research, Vol. 11, Issue 1., 7-12.

Duh, M. 2003. Family enterprises as an importnat factor of the economic development: the case of Slovenia. Journal of Enterprising Culture, 11(2), 111-130. DOI:10.1142/S02 1849580300007X

Expósito, A., Sanchis-Llopis, J.A. 2019. The relationship between types of innovation and SMEs'performance: a multi-dimensional empirical assessment. Eurasian Business Review, 9, 115-135. DOI:10.1007/s40821-018-00116-3

Farrell, A. K., \& Hersch, P. 2005. Additions to Corporate Boards: The Effect of Gender. Journal of Corporate Finance, 11(1-2), 85106. doi:10.1016/j.jcorpfin.2003.12.001

Fischer, E.M., Reuber, A.R., Dyke, L.S. 1993. A theoretical overview and extension of research on sex, gender, and entrepreneurship. Journal of Business Venturing, 8(2), 151-168.

Galbraith Management Consultants. (2013). STAR MODEL. Retrieved January 15, 2013, from Galbraith Management Consultants: http://www.jaygalbraith.com/index.php?option=com_content\&view=article\&id=11\&Itemid=123

Galbraith, J. R. (2012). The Star Molel. Retrieved January 15, 2013, from Emergent Insights: http://blog.emergentconsultants.com/wp-content/uploads/2012/09/StarModelOverview.pdf

Gibrat, R. 1931. Les inegalite economiques. Sirey,.

Gilbert, A.B., McDougall-Covin, P.P., Audretsch, D.B. 2006. New Venture Growth : A Review and Extension. Journal of Management, 36(6), 926-950. DOI:10.1177/0149206306293860

Gimeno, J., Thimothy, B.F., Cooper, C.A., Woo, Y.C. 1997. Survival of the Fittest? Entrepreneurial Human Capital and the Persistence of Underperforming Firms. Administrative Science Quarterly, 42(4), 750-783. DOI:10.2307/2393656

DOI: 10.25103/ijbesar.131.06 
Gobagoba, M. R., Littrell, M.A. 2003. Profiling micro apparel enterprises in Botswana: motivations, practices, challenges and success. Clothing and Textiles Research Journal, $21(3), 130-141$.

Greve, A., Salaff, W.J. 2003. Social Networks and Entrepreneurship. Entrepreneurship Theory and Practice, 28(1), 1-22.

Gupta, V., Turban, D., Wasti, S., Sikdar, A., \& Emirates, D. (2009). The role of gender stereotypes interceptions of entrepreneurs and intentions to become an entrepreneur. Entrepreneurship Theory and Practice, 397-417.

Hart, P.E. 2000. Theories of Firms' Growth and the Generation of Jobs. Review of Industrial Organization, 17(3), $229-248$. DOI: $10.1023 / \mathrm{A}: 1007887626165$

Hassan, R., Marimuthu, M., Johl, K.S. 2016. Women on Boards and Market Performance: An Exploratory Study on the Listed Companies. International Business Management, 10(2), 84-91. doi:10.36478/ibm.2016.84.91

Hernaus, T. (2006). Transformacija klasične organizacije u organizaciju orijetiranu na poslovne procese. Unpublished Master's thesis. Zagreb: Ekonomski fakultet, Sveučilišta u Zagrebu.

Hoxha, D. 2013, Understanding Small Business Growth and Development in Context of an Extreme, Transition and Marginalized Environment, Ph.D thesis, UniversitatAutonoma de Barcelona.

Islam, A.M., Khan, A.A., Obaidullah, A.M., Alam, S.M. 2011. Effect of Entrepreneur and Firm Characteristics on the Business. International Journal of Business and Management, 6(3), 289-299. DOI:10.5539/ijbm.v6n3p289

Islam, M.A., Khan, M.A., Obaidullah, A.M., Alam, M.S. 2011. Effect of entrepreneur and firm characteristics on the business success of small and medium enterprises(SMEs) in Bangladesh. International Journal of Business and Management, 6(3), 289299.

Jovanovic, B. 1982. Selection and the Evolution of Industry. Econometrica, 50(3), 649-670. DOI: 10.2307/1912606

Kalleberg, A.L., Kevin, T.L. 2017. Gender and Organizational Performance: Determinants of Small Business Survivial and Success. Academy of Management Journal, 34(1), 136-161.

Karadzic, V., Drobnjak, R., \& Reyhani, M. (2015). Opportunities and challenges in promoting youth entrepreneurship in Montenegro. International Journal of Business and Economic Sciences Applied Research, Vol. 8, Issue 3., 13-20.

Kepler, E., Shane, S. 2007. Are Male and Female Entrepreneurs Really That Different? The Office of Advocacy Small Business Working Papers.

Kimberley, R.J. 1976. Issues in the Design of Longitudinal Organizational Research. Sociological Methods \& Research, 4(3), 32 1-348.

Loscocco, K., Robinson, J. 1991. Barriers to women's small-business success in the United States.Gender \& Society, 5, pp. . Gender \& Society, 5, 511-532. DOI:United States

Mehmeti, I., Dobranja, D., Hashani, A., \& Beqiri, G. (2017). Women Entrepreneurship: Analysis of doing business in Kosovo. Prishtina: Riinvest Institute.

Murphy, B.G., Trailer, W.J., Hill, C.R. 1996. Measuring performance in entrepreneurship research. Journal of Business Research, 36(1), 15-23. DOI:10.1016/0148-2963(95)00159-X

Newman, W.L. 2006. Research Methods: Qualitative and Quantitative Approaches (6 ed.). USA: Pearson International.

Ostroff, F., \& Smith, D. (1992). The horizontal organization. The McKinsey Quarterly, 1(1), 148-167.

Penrose, E. 1959. The theory of the growth of the firm (3 ed.). New York: Oxford University Press.

Rentzhog, O. (2000). Temelji preduzeća sutrašnjice. Novi Sad: Prometej.

Robb, A., Wolken, J. 2002. Firm, Owner, and Financing Characteristics: Differences between Female- and Male-owned Small Businesses. (T. F. Board, Ed.) Finance and Economics Discussion Series, pp. 1-18.

Robinson, K.C. 1999. An examination of the influence of industry structure on eight alternative measures of new venture performance for high potential independent new ventures. Journal of Business Venturing,14(2),165-187.DOI:10.1016/So8839026(97)00083-9

Rohail, H., Marimuthu, M., Johl, S.K. 2016. Women on Boards and Market Performance: An Exploratory Study on the Listed Companies. International Business Management, 10(2), 84-91. DOI:10.3923/ibm.2016.84.91

Rosli, M.M., Sidek, S. 2013. The Impact of Innovation on the Performance of Small and Medium Manufacturing Enterprises:Evidence from Malaysia. Journal of Innovation Management in Small $\mathcal{E}^{2}$ Medium Enterprise, 1-16. DOI: $10.5171 / 2013.885666$

Rummler, G. A., \& Brache, A. P. (1995). Improving performance: How to manage the white space on the organizational chart, Second edition. San Francisco: Jossey-Bass.

Sapienza, J.H., Grimm, M.C. 1997. Founder Characteristics, Start-Up Process, and Strategy/Structure Variables as Predictors of Shortline Railroad Performance. Entrepreneurship Theory and Practice, 22(1), 5-24.

Shrader, C.B., Blackburn, V.B., Iles, P. 1997. Women in management and firm financial performance: an exploratory study. Journal of Managerial Issues, 9(3), 355-372.

Stewart, T. A., \& Jacoby, R. (1992). The Search for the Organization of Tomorrow. Fortune, 125(10), 92-98.

Storey, J.D. 1994. Understanding the Small Business Sector. In S. E. Forum. London: Routledge.

Trek, S. 2017. Teach yourself statistics . Statistics and Probability Dictionary. Retrieved from Statistics and Probability Dictionary.

Weinzimmer, L.G., Nystrom, P.C., Freeman, S.J. 1998. Measuring organizational growth: Issues, consequences and guidelines. Journal of Management, 24(2), 235-262. DOI:10.1016/S0149-2063(99)80061-0

Whetten, D.A. 1987. Interorganizational relations in J.W. Lorsch. New York, Englewood Cliffs, USA: Prentice-Hall.

Wiklund, J. 1998. Small Firm Growth and Performance: Entrepreneurship and Beyond. Doctoral dissertation. Jönköping: Jönköping International Business School.

Zakić, N. (2009). Inovacije i menadžment poslovnih procesa. Belgrade: Zadužbina Andrejević.

Zhou, H., De Wit, G. 2009. Determinants and dimensions of firm growth. EIM Business and Policy Research,. SCALES Zoetermeer: EIM Research Reports. 